\title{
ANAPHYLAXIS TO THIOPENTONE: A CASE REPORT
}

\author{
David C.W. Chung ${ }^{\circ}$
}

Thropentone is the most used and useful agent in anaesthetic practice. Reports of anaphylactic reaction are rare. Since such reactions are life-threatening, they must be recognized immediately and the appropriate treatment given. A recent case of anaphylaxis to thiopentone is reported.

\section{Case RePort}

A previously healthy 47-year-old white male was admitted to hospital for repair of a ruptured Achilles' tendon. There was no history of allergy. He was not taking any medication. In 1940 he had an uneventful anaesthetic. In 1963 he had an anaesthetic during which he was given thiopentone $250 \mathrm{mg}$, decamethonium $2 \mathrm{mg}$ and succinylcholine $40 \mathrm{mg}$, nitrous oxide and halothane. No adverse reactions were noted.

For the first anaesthetic on this admission, premedication was with papaveretum $10 \mathrm{mg}$ and hyoscine $0.4 \mathrm{mg}$. Induction was with curare $3 \mathrm{mg}$, thiopentone $250 \mathrm{mg}$ and succinylcholine $100 \mathrm{mg}$. Following intubation, he was ventilated with nitrous oxide and oxygen. Ten minutes later, a further $27 \mathrm{mg}$ of curare was given. Following this, there was a progressive fall in blood pressure. Twenty minutes after the start of the anaesthetic, blood pressure recording was unobtainable. Edema of the earlobes, eyelids, lips and hands was noticed. There was neither laryngeal œdema nor bronchospasm and no difficulty in ventilation.

Hydrocortisone hemisuccinate $350 \mathrm{mg}$ and diphenhydramine $50 \mathrm{mg}$ were given intravenously and epinephrine $500 \mu \mathrm{g}$, intramuscularly. After the diphenhydramine, the blood pressure rose to normal levels.

The operation was postponed. The curare was reversed 40 minutes after it was given with atropine $1.2 \mathrm{mg}$ and neostigmine $3.75 \mathrm{mg}$ and the patient was extubated. He was conscious but restless. His vital signs were stable. Two hours later, he was completely normal. The hypotensive incident was attributed to curare.

The operation was rescheduled nine days later. The patient refused to have any form of regional anaesthesia.

In view of the previous history, an allergic reaction was thought possible and drugs for its treatment were made available. The patient was premedicated with diazepam $10 \mathrm{mg}$ and atropine $0.6 \mathrm{mg}$ given intramuscularly. Anaesthesia was induced with pancuronium $6 \mathrm{mg}$ and thiopentone $225 \mathrm{mg}$ given slowly. Towards the end of induction tachycardia developed, the radial pulse felt weak and the entire face became swollen and mildly cyanotic. His trachea was intubated and he was

${ }^{\circ}$ David C.W. Chung, M.D., F.F.A.R.C.S., F.R.C.P.(C), Department of Anaesthesia, University of Toronto and Toronto General Hospital, Toronto, Canada, M5G 1 L7.

Canad. Anaesth. Soc. J., vol. 23, no. 3, May 1976 
ventilated with oxygen. The inflation pressure was high $\left(30-40 \mathrm{~cm} \mathrm{H}_{2} \mathrm{O}\right)$. Diffuse bilateral rhonchi were heard on auscultation of the chest. The blood pressure was unobtainable, but the carotid and femoral pulses were strong. The pupils were small and equal.

Hydrocortisone hemisuccinate $500 \mathrm{mg}$ was given as a bolus injection intravenously followed by chlorpheniramine $10 \mathrm{mg}$ and aminophylline $250 \mathrm{mg}$ over a period of five minutes. Epinephrine $800 \mu \mathrm{g}$ was given intravenously in $200 \mu \mathrm{g}$ increments over the next hour. After the first dose of epinephrine, the radial pulse reappeared and the blood pressure became near normal.

The operation was again postponed. Ventilation was continued for $1 \%$ hours. After atropine $1.2 \mathrm{mg}$ and neostigmine $2.5 \mathrm{mg}$, the trachea was extubated. Four hours after induction, the patient was fully conscious and talking. Six hours after, he was taking sips of water and joking about his experience.

Seven weeks later, after an unsuccessful trial of conservative therapy, he had his tendon repaired under an uneventful epidural anaesthesia with bupivacaine supplemented by droperidol and fentanyl.

\section{DisCUSSION}

Anaphylaxis is a reaction to an antigen to which an organism has been previously sensitized. It usually manifests itself as tachycardia, hypotension, bronchospasm and massive urticaria. It is mediated by massive histamine release. Serotonin, other amines, kinins and slow-reacting substance of anaphylaxis may also play a role.

Reports of thiopentone anaphylaxis are rare. It is not always mentioned as a complication of thiopentone anaesthesia in textbooks of anaesthesia and pharmacology. Nine of 13 reported cases ${ }^{1}$ of thiopentone anaphylaxis had previous exposure to thiopentone. One had thiopentone on 15 occasions. These previous exposures were either uneventful or there were mild reactions not recognized as a manifestation of hypersensitivity. For four patients, it was their first exposure. All four had a history of allergy to drugs or other agents. These patients may have had unsuspected exposure to barbiturates or a cross-sensitivity from other agents. Signs described include coughing during induction, laryngospasm and bronchospasm, massive urticaria and laryngeal oedema, cyanosis, flushing of the skin, nausea and vomiting, diarrhoea, prolonged unconsciousness and tachycardia. Profound arterial hypotension is common to all. No fatal case has been reported.

A diagnosis of thiopentone hypersensitivity is made on clinical grounds. Diagnostic tests have been described by many authors, but they are unrewarding and may be dangerous. The result of the patch skin test ${ }^{2,3}$ is variable and unreliable. Intradermal injection of thiopentone ${ }^{2,3}$ has more predictable results, but wheal and flare may be seen even in the nonallergic subject. The small dose used in intradermal test can precipitate a generalized reaction. Challenge with an intravenous dose is certainly not recommended. Passive transfer of hypersensitivity ${ }^{3}$ (PrausnitzKüstner test) may be useful, but involves injecting the patient's serum into a test subject intradermally. This involves the risk of transmission of serum hepatitis. A precipitating antibody has not been identified. ${ }^{3,4}$ Other in vitro tests include lymphocyte-lymphoblast transformation ${ }^{5}$ and leukocyte challenge. ${ }^{6}$ They are not always conclusive. 
Muscle relaxants were also used in this case. Anaphylaxis to muscle relaxants has been reported but is also rare. Reactions to succinylcholine may be bronchospasm alone ${ }^{7}$ or with hypotension and angioneurotic oedema. ${ }^{8}$ Curare releases histamine. ${ }^{0}$ It also has significant ganglionic blocking effect leading to hypotension. It may be difficult to differentiate these pharmacological effects from true anaphylaxis. Not all reported reactions to curare ${ }^{10-12}$ include hypotension. Pancuronium originally showed no evidence of causing histamine release in man and laboratory animals. ${ }^{13}$ Recently, severe bronchospasm after pancuronium ${ }^{14-17}$ has been reported. Profound hypotension was not a feature of these cases. They may not be allergic reactions. Wheal and flare are produced by intradermal injection of muscle relaxants in both allergic patients and control subjects. This makes interpretation of skin test difficult.

Death from anaphylaxis may occur within five to ten minutes. Treatment must include special attention to ventilation and to cardiovascular support. Oxygen therapy is mandatory and controlled ventilation may be necessary. The first and most important drug to use is epinephrine because it is a vasopressor as well as a bronchodilator. It is a physiological antagonist of released histamine. It also blocks the release of histamine and its effect is immediate. Antihistamines and corticosteroids are only of secondary importance in anaphylaxis. Antihistamines are competitive antagonists of histamine, but once anaphylaxis has occurred they are useless in reversing the immediate effect. There is no evidence that corticosteroids interfere with the immune process involved in hypersensitivity. ${ }^{18}$ Their mechanism of action is ill-understood. Their use in hypersensitivity reaction is empirical and the onset of action is slow. Aminophylline is also a useful bronchodilator. It is a mild myocardial stimulant and enhances the action of epinephrine.

No fatal cases of anaphylaxis to thiopentone have been reported in the literature. However, this is not to underestimate the severity of this reaction. All these cases occurred in the operating room area where facilities for immediate resuscitation are excellent. They were all promptly recognized and treated.

\section{SUMMARY}

A case of anaphylaxis to thiopentone is reported and its immediate treatment with epinephrine is emphasized. Other reported cases of allergic reaction to thiopentone and to muscle relaxants are reviewed. There are no reliable diagnostic tests for allergy to these agents.

\section{RÉSUMÉ}

L'auteur rapporte un cas d'anaphylaxie au thiopental, ainsi que le traitement immédiat de cette condition; l'utilisation de l'adrénaline est soulignée de façon toute spéciale.

Les autres cas de réaction allergique au thiopental et aux relaxants musculaires rapportés dans la littérature ont été revus.

L'auteur souligne enfin qu'il n'existe pas de test fiable pour déterminer l'hypersensibilité à ces agents. 


\section{ADDENDUM}

Four deaths from hypersensitivity reaction to thiopentone were mentioned in an editorial in the British Journal of Anaesthesia ${ }^{19}$ since this article was submitted. No details were given.

\section{REFERENCES}

1. Dundee, J.W. \& Wyant, G.W. Intravenous Anaesthesia, p. 105. Edinburgh: Livingstone (1974).

2. Anderton, J.M. \& Hopton, D.S. Thiopentone anaphylaxis. Anaesthesia 23: 90 (1968).

3. Currie, T.T., Whittingham, S., Ebhinger, A., \& Petens, J.S. Severe anaphylactic reaction to thiopentone: case report. $\mathrm{Br}$. Med. J. 1: 1462 (1966).

4. Carrie, L.E.S. \& Buchanan, R.L. Thiopentone anaphylaxis. Anaesthesia 22: 290 ( 1967 ).

5. Clark, M.M. \& Cockburn, H.A. Anaphylactoid response to thiopentone. Br. J. Anaesth. 43: 185 ( 1971$)$.

6. Dundee, J.W., Assem, E.S.K., Gaston, J.M., Keilty, S.R., Sutron, J.A., Clarke, R.S.J., \& Grainger, D. Sensitivity to intravenous anaesthetics: a report of three cases. Br. Med. J. 1: $63(1974)$.

7. Sмiтh, N.L. Histamine release by suxamethonium. Anaesthesia 12: 293 (1957).

8. Jerums, G., Whitringham, S., \& Wilson, P. Anaphylaxis to suxamethonium. Br. J. Anaesth. 39: 73 (1967).

9. Alam, M., Anrep, G.V., Barsoum, G.S., Talaat, M., \& Wieninger, E. Liberation of histamine from the skeletal muscle by curare. J. Physiol. (London) 95: 148 (1939).

10. Brandus, V., Joffe, S., \& Rubin, J.M. Histamine-like reaction to tubocurarine. Br. J. Anaesth, 45: 108 (1973).

11. Hainsworth, A.M. \& Bingham, W. An allergic circulatory collapse following the administration of muscle relaxants. Anaesthesia 25: 105 (1970).

12. SALEM, M.R., KIM, Y., \& EL ETR, A.A. Histamine release following intravenous injection of d-tubocurarine. Anesthesiology 29:380 (1968).

13. Bucket', W.R., Marjonibanks, C.E.B., Marwick, F.A., \& Morton, M.B. The pharmacology of pancuronium bromide, a new potent steroidal neuromuscular blocking agent. Br. J. Pharmacol. Chemoth. 32: 671 (1968).

14. Buckland, R.W. \& Avery, A.F. Histamine release following pancuronium. Br. J. Anaesth. 45: $518(1973)$.

15. Clark, R.M. Reaction to pancuronium. Br. J. Anaesth. 45: 997 ( 1973 ).

16. Нелтн, M.L. Bronchospasm in an asthmatic patient following pancuronium. Anaesthesia 28: 437 (1973).

17. Tweedie, D.G. \& Ordish, P.M. Reactions to intravenous agents (Althesin and pancuronium ). Br. J. Anaesth. 46: 244 ( 1974 ).

18. Goodman, L.S. \& Gilman, A. The Pharmacological Basis of Therapentics, 5th ed., p. 1487. New York: Macmillan (1975).

19. DundeE, J.W. Hypersensitivity to intravenous anaesthetic agents. Br. J. Anaesth. $48: 57$ $(1976)$. 